\author{
Agnieszka Czyżak \\ Instytut Filologii Polskiej \\ Uniwersytet im. Adama Mickiewicza w Poznaniu \\ e-mail: agaczyz@amu.edu.pl \\ ORCID: 0000-0001-8918-5264
}

\title{
O dywersyfikacji pojęć przestrzennych - zyski i straty
}

Na początek dwa fragmenty arbitralnie dobranych haseł słownikowych. Pierwszy - z polskiego leksykonu wydanego w 2014 roku:

Sposób rozumienia miejsca znajduje odzwierciedlenie w poglądach na temat czynników odpowiedzialnych za pamięć miejsc. Według Paula Connertona pamięć miejsca może przyjmować dwie formy umiejscowienia (locus) oraz upamiętnienia (memorial) [...]. Pamięć typu locus jest pamięcią ucieleśnioną, cechuje osoby długo mieszkające w danym miejscu i doświadczające go „od wewnątrz", podczas gdy pamięć typu upamiętnienie jest „zimną" wiedzą zewnętrznego obserwatora ${ }^{1}$.

I drugi - z encyklopedii opublikowanej w Wielkiej Brytanii w roku 1996:

Antropolodzy miasta realizują swoje cele, stosując zarówno podejście odgórne, jak i oddolne. Tradycja badań mikro dokumentujących życie codzienne jest dobrze ugruntowana $w$ badaniach migracji, sieci powiązań społecznych, gangów ulicznych, społeczności sąsiedzkich, procesów politycznych [...]. Jednak tak samo dobrze ugruntowane są ujęcia całościowe, które opisują formy i jakości wiejskości, wymiar (opozycji) wiejskości-miejskości, zróżnicowane heterogenetyczne i ortogenetyczne ośrodki miejskie, lokalny i międzynarodowy ład społeczny,

1 M. Lewicka, Miejsce, w: Modi memorandi. Leksykon kultury pamięci, red. M. Saryusz-Wolska, R. Traba, Warszawa 2014, s. 228. 
sieci marketingowe, [...] symbolizm przestrzenny, międzykulturowe wymiary życia miejskiego ${ }^{2}$.

Fragment hasła "miejsce” z Leksykonu kultury pamięci pod redakcją Magdaleny Saryusz-Wolskiej i Roberta Traby ukazuje, w jaki sposób elementy dyskursu przestrzennego współtworzą poszczególne (taktowane albo jako węższe subdyscypliny albo jako odrębne pola działań naukowych) nurty badawcze. Nadto stając się ich językiem, prowadzą do rozszczelnienia naukowego wywodu i prowokują do używania metafor, symboli czy też osadzonych w potocznym doświadczeniu paraleli.

Z kolei fragment hasła "antropologia miasta” z Encyklopedii antropologii społeczno-kulturowej pod redakcją Alana Barnarda i Jonathana Spencera uświadamia, iż właśnie badania terenowe, penetrowanie określonych przestrzeni legły $u$ podstaw nie tylko antropologii, ale i socjologii, etnografii czy dialektologii. To empiryczny - czy raczej osobisty - kontakt z badaną materią już od pierwszych podejmowanych prób leżał u podstaw formułowanych teorii. Oba przywołane fragmenty pokazują natomiast $z$ jednej strony rudymentarną potrzebę rozwijania badań nad przestrzenią, z drugiej zaś specyficzną "łączliwość" dyskursu przestrzennego, z łatwością wchłanianego przez inne dyskursy.

Termin „dywersyfikacja” - pożyczony z nauk ekonomicznych - oznacza różnicowanie asortymentu produkcji lub usług w celu zmniejszenia ryzyka. W praktyce dywersyfikacja może być realizowana nie tylko poprzez wprowadzenie nowych produktów, ale także poprzez wzrost liczby obszarów działalności, pozyskiwanie nowych rynków zbytu, poszerzenie kręgu dostawców i odbiorców. Jednak przez dywersyfikację zmniejsza się nie tylko prawdopodobieństwo straty, ale też prawdopodobieństwo najwyższego zysku tym samym rozszerzanie asortymentu i rynków zbytu to wynik ostrożności, obawy przed ryzykiem, jakie pociąga za sobą wąska specjalizacja. I tu pojawia się pytanie: czy zwrot topograficzny (przestrzenny, spacjalny), który dał początek rozmaitym subdyscyplinom, dziś rozwijającym się z wielkim powodzeniem, był rzeczywiście „zwrotem” w badaniach teoretycznych, a tym samym doprowadził do wykształcenia się nowej gałęzi humanistycznych poszukiwań, czy raczej przyczynił się do przeobrażenia sposobów formułowania i funkcjonowania rozmaitych (nie tylko) humanistycznych dyskursów, przez co pozostaje ich zwielokrotnianą i różnorako modyfikowaną "częścią wspólną".

2 W. Dostal, A. Gincrich, Antropologia miasta, przeł. M. Sadurska, w: Encyklopedia antropologii społeczno-kulturowej, red. A. Barnard, J. Spencer, Warszawa 2008, s. 93. 
"Zwroty" we współczesnej teorii literatury i kultury pojmowane jako poręczne narzędzie systematyzowania przemian służą ustalaniu punktów orientacyjnych na osi czasu oraz porządkowaniu („mapowaniu”) obszarów badawczych. Ich swoisty „nadmiar" ufundowany został w istocie na realnej potrzebie przebudowy języka służącego do opisu kulturowej rzeczywistości, czy raczej mnożenia równoprawnych języków, wchodzących w coraz to nowe (nie zawsze trwałe) sojusze. Zwrot topograficzny - datowany z reguły na przełom lat siedemdziesiątych i osiemdziesiątych, wtedy bowiem wiązka wyrazistych wcześniejszych inspiracji zaczęła być postrzegana jako osobny projekt poznawczy - miał jednak i inny wymiar. Nie tylko pozwalał konstatować zjawiska zachodzące $\mathrm{w}$ dziedzinie badań nad tekstami kultury, ale także diagnozować przemiany o szerszym zasięgu, zarówno politycznym, społecznym, ideologicznym, jak i związanym z mechanizmami wytwarzania reguł zbiorowego życia. Przekonanie, że modernizm był epoką czasu (historii, ewolucji, postępu), doprowadziło wówczas do różnorako konfigurowanych twierdzeń, iż postmodernizm określić można epoką przestrzeni (równoczesności, konstelacji, entropii), co w oczywisty sposób na obszarze humanistyki musiało wpłynąć nie tylko na sposób zakreślania granic przedmiotu badań, ale i wytwarzania mechanizmów koegzystowania równoprawnych szkół interpretacyjnych.

Świadomość determinującej roli przestrzennych uwarunkowań egzystencji łączyła się z postrzeganiem ludzkiej aktywności jako „umiejscowionej” - niezależnie od tego, czy było to statyczne trwanie w określonym punkcie, czy dynamiczne zdobywanie nowych obszarów. Przedstawienie długotrwałych skutków zwrotu topograficznego, ze względu na ich wielość, wielopostaciowość oraz procesualną naturę pozostać musi przybliżeniem (a zatem i zawężeniem) oglądu zjawiska oraz ujęciem pozwalającym zaledwie wskazać punkty orientacyjne w rozległym polu praktyk kulturowych. Niemniej jednak to właśnie owe nieusuwalne konsekwencje wskazują na wagę dyskursywnego przełomu.

Popularność przestrzennych metafor, określających nie tylko formy uczestnictwa w kulturze i życiu codziennym, ale i pole (zakres, zasięg) podejmowanych wysiłków ich konceptualizacji, poświadcza niezbywalną trwałość skutków (wynikających $\mathrm{z}$ owych procesualnie postępujących zmian) także w potocznych praktykach werbalizowania doświadczeń. Niejako „naturalne" porządkowanie egzystencji jednostkowej i zbiorowej poprzez "spacjalne" konstrukty językowe sprawia, iż kategorie przestrzenne postrzegane są jako wspólna własność uczestników komunikacji. Badanie przestrzeni, czy choćby opowiadanie o niej w szczególny sposób, pozwala ujawniać osobisty charakter więzi z miejscem, podmiotowy akt lokowania się w świecie - wszak 
łączność z przestrzenią ma charakter zarówno organiczny (fizjologiczny), jak i intelektualno-emocjonalny (duchowy). Na poziomie afektów - przedwerbalnych psychocielesnych doznań - wyzwala się zdolność zaakceptowania własnego miejsca w świecie.

Jednostkowe więzi z przestrzenią współtworzą sieć relacji społecznych, a zarazem są przez nie determinowane. Doris Bachmann-Medick w Cultural Turns podkreślała skalę przekształceń w postrzeganiu przestrzeni, która przestała ostatecznie funkcjonować jako materialne tło ludzkiej aktywności, a zaczęła jawić się jako społeczny proces wytwarzania mechanizmów percepcji, użytkowania i przyswajania, „ściśle powiązany z symboliczną płaszczyzną reprezentacji przestrzennej (np. przez kody, znaki, mapy)"3. Rosnące zainteresowanie przestrzennym wymiarem doświadczeń rozszerzało perspektywę oglądu zjawiska, stąd dziś „przestrzen" nie bywa już postrzegana wyłącznie jako wielorako definiowany przedmiot badań. Tym samym zwrot topograficzny, jak podkreśla Elżbieta Rybicka, nie ogranicza się do wzrostu zainteresowania kategoriami spacjalnymi:

Uznanie przestrzeni za czynnik sprawczy współczesnej myśli teoretycznej i praktyk badawczych doprowadziło wszak - $\mathrm{i}$ to chyba należy uznać za fakt najistotniejszy - do przeformułowania innych podstawowych pojęć: języka, podmiotu, kultury, praktyk literackich i artystycznych, a wreszcie samych badań i sytuacji badacza ${ }^{4}$.

Rybicka, podkreślając istotę przemian w sferze procesów poznawczych, które zmieniły optykę myśli osiadłej w perspektywę myśli nomadycznej, wskazywała również na wymiar niezbywalny podejmowanych rozważań, czyli „praktykowanie" przestrzeni, jednostkowe i wspólnotowe akty jej wytwarzania.

Kategorie przestrzenne szybko ujawniły to, co w nich najistotniejsze, a więc swój rzeczywisty status koniecznego aspektu, perspektywy czy też kontekstu najrozmaitszych badań. Zmianę oglądu kondycji człowieka w przestrzeni współtworzyły procesy globalizacji (determinujące coraz więcej sfer aktywności jednostek i społeczeństw) oraz wcale nie przeciwstawne

\footnotetext{
3 D. Bachmann-Medick, Spatial Turn, w tejże: Cultural Turns. Nowe kierunki w naukach o kulturze, przeł. K. Krzemieniowa, Warszawa 2012, s. 346. Badaczka zatytułowała pierwszy rozdział swojej rozprawy Kartografia nauk o kulturze, w nim przedstawiła „próby mapowania badań kulturoznawczych, ich krajobrazu teoretycznego i dyskusji" [s. 7], by dojść do pesymistycznej diagnozy statusu współczesnych „zwrotów” w teorii kulturowej, które są jak „ubiory, które wychodzą z mody" [s. 62].

4 E. Rybicka, Geopoetyka. Przestrzeń i miejsce we wspótczesnych teoriach i praktykach literackich, Kraków 2014, s. 59.
} 
im powroty rozmaitych odmian i przejawów dążenia do „lokalności”. Podobne znaczenie mają procesy rozszerzania się wirtualnych sfer komunikacji i kumulacji wiedzy. Rzeczywistość wytwarzana w sferze cyfrowej aktywności oraz kreowane $\mathrm{w}$ jej ramach metody zawłaszczania ludzkiej wyobraźni postrzegane są coraz częściej jako nieodłączna (a także „namacalna") sfera codziennych działań. Natomiast narzędzia służące do „poruszania się" w przestrzeni nowych mediów uznawane są za protezy umożliwiające dostęp do wirtualnego świata. Przymus wizualizowania wszelkich elementów i procesów rzeczywistości okazał się wstępem do powszechnej wirtualizacji. Zwraca również uwagę ciążenie języka wytwarzanego na potrzeby nazywania czynności wykonywanych w sieciowej rzeczywistości ku metaforom przestrzennym, pozwalającym nowy rodzaj doświadczeń oswoić i zinterioryzować. Natomiast umacniająca się wciąż świadomość globalistyczna ma swoje źródła w medialnym zawłaszczeniu przestrzeni komunikacji i zwielokrotnieniu sposobów jej użytkowania.

Równolegle należy podkreślić trwałą ważność kategorii miejsca oraz interpretacyjną użyteczność jej opozycyjnych wariantów: miejsca własne-cudze, piękne-straszne, otwarte-zamknięte, przyjazne-wrogie oraz oczywiście opozycji podstawowej - miejsca i nie-miejsca, szczególnie w obszarze badań nad problemami podmiotowości, identyfikacji i tożsamości ${ }^{5}$. Podobne znaczenie ma kategoria miejsca autobiograficznego otwierająca pole do analizowania związków między przestrzenią a poznającym/konstruującym ją podmiotem ${ }^{6}$. Natomiast nieustające ludzkie pragnienie, by podróżować, a zarazem przetwarzać zdobyte doświadczenia w teksty kultury doprowadziło do powstania swoistego nadmiaru tekstów dotyczących konkretnych miejsc. Niezliczone przewodniki, poradniki, zestawienia, rankingi turystycznych atrakcji powstają nie tylko $\mathrm{w}$ ramach zinstytucjonalizowanych i skomercjalizowanych działan - Internet pełen jest dobrowolnie pozostawianych świadectw podróży, śladów obecności w nowych miejscach oraz dokonywanych nadzwyczaj chętnie wartościujących ocen i hierarchizujących zestawień, w których poznawane „punkty na mapie” przekształcane są w rankingi ufundowane na osobistym doświadczeniu.

Bedekery, informatory, przewodniki być może przyczyniają się do tego, że najbardziej popularne miejsca zmieniają swój status ontologiczny na pełną widm krainę, której „istotę" trudno wydobyć spod masy nawarstwiających

\footnotetext{
5 Zob. m.in. M. Czermińska, Tożsamość kształtowana w pamięci miejsca, w: Kulturowa historia literatury, red. A. Łebkowska, W. Bolecki, Warszawa 2015.

6 Zob. M. Czermińska, Miejsca autobiograficzne, Propozycja w ramach geopoetyki, „Teksty Dru-

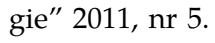


się tekstów ${ }^{7}$ - one same jednak tworzą kolejny obszar badawczy wart osobnego namysłu ${ }^{8}$. Podróż oraz wszelkie jej odmiany, zarówno subwersywna włóczęga, jak i komercyjna turystyka, pozwalają wytwarzać złudzenie panowania nad przestrzenią, przekraczania granic, wyzwalania się z wąskich ram codzienności, rozpoznawania skomplikowanych relacji między "domem" a „światem" 9 . Wielkie znaczenie ma także fakt, iż każda „peregrynacja” nieuchronnie ciąży (również, a może przede wszystkim w potocznym odbiorze) ku metaforycznym ujęciom życia jako wędrówki, zatem analizowanie jej kulturowych obrazów (także tych wytwarzanych na własny użytek) prowadzi ku samopoznaniu i pozwala na budowanie dystansu wobec reguł egzystencji.

Obok obserwowanego dziś specyficznego „uwspólnienia” dziedzictwa przestrzennych rozpoznań zauważyć można ruchy świadczące o wyczerpywaniu się pionierskiego zapału, by zakreślać wyraźnie granice pól badawczych czy wyostrzać narzędzia analityczne. Dariusz Czaja w tekście Nie-miejsca. Przybliżenia, rewizje postanowił na przykład zbliżyć do siebie heterotopie Michela Foucault oraz nie-miejsca Marca Augé, po to, by zwiększyć pojemność znaczeniową i przydatność interpretacyjną „nowej” kategorii:

Jeśli pozbawić nie-miejsca negatywnego wartościowania, a heterotopie wyposażyć w parametr chronologiczny, to można zbliżyć je do siebie i wykorzystać jako pożyteczną kategorię operacyjną. „Heterotopicznym nie-miejscem” byłyby w tym samym stopniu dworce, lotniska i hotele (Augé), co cmentarze, ogrody i archiwa (Foucault) ${ }^{10}$.

W konsekwencji, jak podkreśla Czaja, do ogromnego, płynnego i wciąż nieskatalogowanego archipelagu nie-miejsc będzie można dopisywać nowe obszary, także (czy raczej przede wszystkim) takie, o których „projektodawcy wspomnianych kategorii w ogóle nie pomyśleli"11. Rodzi się tu jednak natychmiast wątpliwość: czy będzie można wówczas stworzyć definicję

7 Zob. G. Agamben, O zaletach i niedogodnościach życia wśród widm, w tegoż: Nagość, przeł. K. Żaboklicki, Warszawa 2010. Agamben pisał o skutkach nadmiernego utekstowienia miejsc: „W Wenecji wszystko to, co zdarzyło się na danej uliczce, na danym placu, na danym chodniku wzdłuż kanałów, w danym zaułku, kondensuje się nagle i krystalizuje w figurę zarazem chwiejną i wymagającą, niemą i poufałą, poirytowaną i odległą. Ta figura to widmo albo duch opiekuńczy miejsca" [s. 49].

8 Zob. Geoliteratura. Poradnik, bedeker, przewodnik, red. J. Madejski, S. Iwasiów, Szczecin 2018.

9 Zob. J. Abramowska. Peregrynacja, w: Przestrzeń i literatura, red. M. Głowiński, A. Okopień-Sławińska, Wrocław 1978.

10 D. Czaja, Nie-miejsca. Przybliżenia, rewizje, w: Inne przestrzenie, inne miejsca. Mapy i terytoria, red. D. Czaja, Wołowiec 2013, s. 22.

11 Tamże. 
nie-miejsca? I czy nie doprowadzi to do powrotu do najprostszej opozycji: miejsca dobre-złe (czyli znów locus amoenus i locus horridus o antycznym rodowodzie)?

Opowieści o przestrzeni, od początku uwikłane w role służebne, i dziś pełnią funkcje terapeutyczne i dydaktyczne. Marta Zielińska w tekście Krajobraz po zwrocie tak wyjaśniała ważność tekstowych ufundowań w oswajaniu przestrzeni: „Przeciwwagą dla narastającej dystrofii miejsc rzeczywistych i naszej w nich dezorientacji są kreacje literackie, a także prace naukowe i popularnonaukowe, upowszechniające narracje o warstwach ich przeszłości i palimpsestowym, heterotopicznym charakterze" ${ }^{12}$. Poczuciu niepewności, bezradności zagubienia przeciwstawić można porządek dyskursywny stabilizujący sytuację podmiotu (lub ją modelujący) na użytek prowadzonych rozważań ${ }^{13}$.

Podobne cele można zauważyć $\mathrm{w}$ działaniach związanych $\mathrm{z}$ rozwojem Nowego Regionalizmu, w ramach którego badacze włączają się w lokalną wspólnotę i współtworzą reguły jej funkcjonowania. Małgorzata Mikołajczak w swoim projekcie regiopoetyki (a także - regiokrytyki konceptualizowanej na wzór geopoetyki) wskazywała na wagę opowieści zawierających alternatywne wersje kultury - niekanoniczne, kontrhegemoniczne, a zarazem podtrzymujące lokalne więzi. Teksty konkurencyjne wobec dominującej, narodowej narracji mogłyby zdaniem badaczki przekazywać odbiorcom inne/szersze spektrum wartości:

kładąc nacisk na afirmatywność - regiopoetyka może służyć „ratowaniu” miejsca, jakim jest region w jego wymiarze geograficznym oraz kulturowo-społecznym. Może zarówno przyczyniać się do gromadzenia i powstawania wiedzy na temat regionalnej przeszłości, jak i do wytwarzania wiedzy o charakterze integrującym oraz wspólnotowym ${ }^{14}$.

Tak pojmowana lokalność służyłaby zatem kształtowaniu „przyjaznej” przestrzeni, pozwalającej na odnalezienie sposobu na zaakceptowanie danego/wybranego miejsca $w$ ramach pojedynczej egzystencji, pozostającej

12 M. Zielińska, Krajobraz po zwrocie, „Teksty Drugie” 2014, nr 6, s. 15.

13 Czynił tak na przykład Zygmunt Bauman próbując „uporządkować” nowożytne dzieje ludzkości: „Gdzieś po drodze od wczesnonowożytnej utopii - pozytywnej, swawolnej, asertywnej, pewnej swego - do dzisiejszej retrotopii - niepewnej, zgnębionej i defetystycznej Pigmalion [...] który uległ czarowi własnoręcznie wyrzeźbionej w kości słoniowej Galatei, napotkał Narcyza, który pokochał swe własne piękne oblicze - ale w ostatniej opowieści ukochane odbicie migocze na powierzchniach, które zdolne są tylko je odbijać" [Z. Bauman, Retrotopia. Jak rządzi nami przeszłość, przeł. K. Lebek, Warszawa 2018, s. 212].

14 M. Mikołajczak, Regiopoetyka? Wstępne uwagi na temat nowego projektu, „Poznańskie Studia Polonistyczne. Seria Literacka" 2017, nr 30, s. 82. 
w świadomie wytwarzanej więzi z życiem zbiorowości - zamieszkującej region, krainę geograficzną, a nade wszystko miasta. Kim jednak okazuje się $\mathrm{w}$ tej sytuacji badacz? Zaledwie akuszerem rodzących się więzi lub opiekunem tych gasnących, w trudzie przedłużającym ich trwanie - zatem raczej zaangażowanym członkiem wspólnoty niż zdystansowanym wobec zjawisk uczonym. $Z$ drugiej strony jednak to kolejne szeroko otwarte podwoje przed badaczami pragnącymi uprawiać tzw. „literaturoznawstwo osobiste" 15 , pozwalające legitymizować własne istnienie w świecie i odrzucające opozycję afektu i intelektu.

Miejsce jako punkt odniesienia interpretacyjnych i porządkujących rozpoznań jest zarazem punktem, w którym splata się perspektywa emocjonalna i intelektualna. Widać to szczególnie wyraźnie w najnowszych - ujmowanych niezwykle szeroko, interdyscyplinarnie i międzyobszarowo - studiach miejskich (urban studies). Miasto pozostaje bowiem nieodmiennie niezwykle istotnym centrum badań nad przestrzenią. Nie tylko dlatego, że większa część populacji naszego globu to mieszkańcy miast - powodem niezwykle ważnym jest specyfika funkcjonowania miasta jako tworu o niejednorodnym, skomplikowanym charakterze (na wszystkich poziomach egzystencji zbiorowej) oraz jego wielopostaciowa rola $\mathrm{w}$ determinowaniu życia jednostek. Badanie miast uznaje się dziś za równoznaczne z przekraczaniem bariery tekstowych świadectw. Katarzyna Szalewska pisała w Urbanaliach:

Wyjście poza mapę miejską to także wyjście poza tekst. Ten sam ruch musi się dokonać w refleksji nad humanistycznymi studiami miejskimi. Przestrzeń urbanistyczna jako twór heterogeniczny domaga się namysłu jednocześnie nad literaturą i formami nieliterackimi, tekstowymi reprezentacjami miasta i tekstami dosłownie usytuowanymi w mieście ${ }^{16}$.

Badaczka wskazywała na wagę „performatyki urbanistycznej”, czyli doświadczania i opisywania miasta tożsamych z jego konstruowaniem. Analiza miejskich świadectw, uwzględniająca „paralelizm między zdarzeniowością miasta (jako tekstu) i tekstem literackim (jako zdarzeniem)" ${ }^{17}$, wyznacza również bycie-w-mieście podmiotu poznającego. Projekty realnego zdobywania przestrzeni jako metody badawczej, obecne już we wczesnych pracach Ewy Rewers ${ }^{18}$, okazują się nie tylko sposobem pochwycenia jej specyfiki, ale

\footnotetext{
15 Zob. R. Nycz, Tekstowe doświadczenia, „Teksty Drugie” 2010, nr 1/2.

16 K. Szalewska, Urbanalia - miasto i jego teksty. Humanistyczne studia miejskie, Gdańsk 2017, s. 11 .

17 Tamże.

18 Zob. E. Rewers, Post-polis. Wstęp do filozofii ponowoczesnego miasta, Kraków 2005.
} 
i drogą ku samopoznaniu. W efekcie prowadzi to do silniejszego naruszenia zwyczajowych reguł „opisywania” miejsc. Podobnie próby wytwarzania genderowego obrazu miast ${ }^{19}$ służyć muszą przede wszystkim rozbijaniu tradycyjnych sposobów postrzegania przestrzennych porządków.

Z kolei Agata Skórzyńska w książce Praxis i miasto postanowiła powiązać swoje badania z procesualnymi i performatywnymi koncepcjami wiedzy, zakładającymi, iż przeprowadzanie badań powinno polegać na stałym aktualizowaniu kompetencji, praktykowaniu, uczeniu się. Twierdziła tam z przekonaniem:

$\mathrm{w}$ ramach dostępnych form myślenia kulturalistycznego potrzebne jest specyficzne przemieszczenie ontologiczne - postawienie teorii „z głowy na nogi”, sprowadzenie ich na ziemię, na szorstki grunt rzeczywistości. [...] W perspektywie praktycznej chodzi o to, abyśmy dostępne nam sposoby teoretycznego ujmowania kultury potraktowali jako performatyw, a nie konstatyw. Nie jako obszar rzeczywistości, lecz jako czynność odnoszenia się do niej ${ }^{20}$.

Podtytuł rozprawy Ćwiczenia z kulturowych badań angażujących wskazuje na wagę owego wyzbytego obiektywizmu „zaangażowania”, potrzebę emocjonalnego nacechowania działań.

Emocje jako język służący translacji głębokich, afektywnych więzi z przestrzenią są już pełnoprawną ramą interpretacyjną. Aleksandra Kunce w książce Człowiek lokalny stwierdziła wprost:

Bez miłości nie ma filozofii miejsca. Jeśli miejsce nie ma tej szczeliny - tego przesmyku do wieczności, to nie ma "miejsca” w miejscu. Pozostaje jedynie obszar złowrogi, nijaki, obcy, zamknięty. Miejsce, prawdziwe miejsce, powinno być zaproszeniem do miłości. Filozofia lokalności naprowadza na podjęcie umiejscowienia mojego losu między utratą i wzrostem, pokorą i mocą ${ }^{21}$.

Miłość postawiona przeciw nienawiści (niechęci, obrzydzeniu) pozwala zadomowić się $\mathrm{w}$ przestrzeni. Natomiast emocjonalna więź z przedmiotem/obszarem badań po raz kolejny staje się drogą ku coraz popularniejszej odmianie humanistycznych poszukiwań łączonych z odsłanianiem szerokiej skali osobistych interakcji ze światem.

\footnotetext{
19 Zob. S. Chutnik, Zabawy w pamięć i genderowy obraz miasta. Próba konceptualizacji praktycznej, „Teksty Drugie" 2014, nr 6.

20 A. Skórzyńska, Praxis i miasto. Ćwiczenia z kulturowych badań angażujących, Warszawa 2017, s. 16.

21 A. Kunce, Człowiek lokalny. Rozważania umiejscowione, Katowice 2016, 53-54.
} 
Jak przekonuje Ryszard Nycz, współczesnym zadaniem humanistyki okazuje się zdobywanie nowych obszarów. Nowa humanistyka ciąży ku wytwarzaniu przestrzeni interdyscyplinarnych czy międzyobszarowych. Postawa wobec tak konstruowanych pól badawczych musi pozostawać aktywnością angażującą nie tylko intelektualne sfery poznawcze. Nycz podkreśla: „Świat nowej humanistyki to, po pierwsze i przede wszystkim, świat immanencji, rzeczywistość partycypacji, poznania od wewnątrz, poznania uczestniczącego" ${ }^{22}$. W pięciu wyznaczonych przez badacza głównych nurtach humanistycznych poszukiwań istotne jest dążenie do rozszerzenia tradycyjnych obszarów i przekraczania granic metodologicznych (co oczywiście najłatwiej opisać za pomocą przestrzennych porównań i metafor). W takim ujęciu humanistyka cyfrowa zagospodarowuje przestrzeń wirtualną, humanistyka zaangażowana jest formą interwencji w sferze dyskursów publicznych, humanistykę kognitywną charakteryzuje perspektywa "podmiotu w środowisku”, zadanie posthumanistyki stanowi eksploracja ekosystemu "kulturonatury" jako uniwersum podmiotowej aktywności, natomiast dla humanistyki artystycznej istotna jest „inkluzja sztuki jako narzędzia i medium twórczego poznania" ${ }^{23}$. Nie trzeba nawet pytać, gdzie na tak wyznaczonym polu zajmują miejsce badania nad przestrzenią - ich rozpoznania stały się zasymilowaną samoświadomością epistemologiczną badaczy i szkół interpretacyjnych.

$\mathrm{W}$ polskim literaturoznawstwie istotnym impulsem rozwoju przestrzennego kategoryzowania zjawisk stała się seria przekładów zamieszczonych w „Pamiętniku Literackim” z 1976 roku pod wspólnym tytułem Przestrzeń $w$ dziele literackim. Gérard Genette w artykule Przestrzeń $i$ język już wówczas stwierdzał jednoznacznie: „cały nasz język jest utkany z przestrzeni" 24, a Gaston Bachelard odsłaniał projekt ,topo-analizy przestrzeni intymności” 25 . Natomiast Jurij Łotman rozpoczynał swój tekst od wskazania relacji: „Zainteresowanie problematyką przestrzeni artystycznej stanowi konsekwencję myślenia o dziele jako o swoiście odgraniczonej przestrzeni, która przedmiot nieskończony - świat wobec dzieła zewnętrzny - oddaje za pomocą swojej skończoności" ${ }^{26}$. W następnych latach polscy badacze podjęli wskazane przez europejskich badaczy zadanie, choć zrazu jakby niechętnie. W arty-

22 R. Nycz, Nowa humanistyka w Polsce: kilka bardzo subiektywnych obserwacji, koniektur, refutacji, „Teksty Drugie" 2017, nr 1, s. 37.

23 Tamże.

24 G. Genette, Przestrzeń i język, przeł. A. W. Labuda, „Pamiętnik Literacki” 1976, z. 1, s. 231.

25 G. Bachelard, Poetyka przestrzeni: szuflada, kufry i szafy, przeł. W. Krzemień, „Pamiętnik Literacki" 1976, z. 1, s. 241.

26 J. Łotman, Problem przestrzeni artystycznej, przeł. J. Faryno, „Pamiętnik Literacki” 1976, z. 1, s. 213. 
kule z 1978 roku, który miał swój pierwodruk w tomie Przestrzeń i literatura, Janusz Sławiński tak podsumowywał ówczesną ekspansję "tematyki przestrzennej":

repertuar współtworzących ją kwestii pozostaje otwarty i obecnie wydaje się niemal bezgraniczny. Skoro niewiele zostało w nim definitywnie ustalone - wiele jeszcze może być przywłaszczone skądinąd. Jesteśmy więc świadkami żywo rozwijającej się akcji translacyjnej; na język spraw przestrzennych przekłada się teraz rozliczne zagadnienia ujmowane przedtem $\mathrm{w}$ innych kategoriach i terminologiach ${ }^{27}$.

Dla badaczy wywodzących się z nurtów strukturalistyczno-semiotycznych niepokojąca wydawała się nie tyle sama ekspansja kategorii przestrzennych, ile ich (jakoby nie do końca uprawniony) wszechogarniający i nadrzędny wobec innych rozpoznań charakter. Niepokoiła - z ich punktu widzenia redundantna - konieczność przekładania (niemal mechanicznego) dotychczasowych rozpoznań na język przestrzenny. To oczywiście niesprawiedliwe uproszczenie - badacz nie mógł w owym czasie przewidzieć skali, zakresu i głębi przemian, do jakich przyczynił się zwrot przestrzenny.

Po upływie niemal dwóch dekad XXI wieku i równo czterdzieści lat po publikacji artykułu Sławińskiego rzeczywisty status badań nad przestrzenią wydaje się nie do podważenia. Rozwój dyscyplin wyrosłych na gruncie zwrotu topograficznego przyniósł rozliczne pożytki w sferze interpretowania kondycji człowieka, a chociaż pierwsze rozpoznania i ustalenia zostały niejako wchłonięte przez większość nurtów współczesnej humanistyki, to stanowią wspólną płaszczyznę epistemologiczną kulturowych eksploracji, zbiór ich swoistych „miejsc wspólnych”. Wypracowane pojęcia stały się elementami współtworzącymi nie tylko powszechnie zrozumiałą, poszerzoną metaforykę spacjalną, ale i zestaw bardziej wyspecjalizowanych narzędzi interpretacyjnych. Można znaleźć je wszędzie - i pomimo tego, że zazwyczaj ich użycie bywa upodrzędnione wobec potrzeby wytwarzania dyskursów badawczych bardziej aktualnie modnych czy ekspansywnych, pozostają ich częścią rudymentarną. Jaka zatem będzie przyszłość badań nad przestrzenią? Czy stanie się czymś więcej niż wygodnym instrumentarium analitycznym oraz repozytorium klasycznych tekstów metodologicznych i zbiorem niepodważalnych teoretycznych ustaleń? Rysuje się tutaj wiele możliwości, powiązanych z przyspieszonym rozwojem cywilizacyjnym.

27 J. Sławiński, Przestrzeń w literaturze: elementarne rozróżnienia i wstępne oczywistości, w: Przestrzeń w literaturze, red. M. Głowiński, A. Okopień-Sławińska, Wrocław 1978, s. 9. 
Nowa humanistyka musi bronić się przecież nie tylko przed różnymi próbami marginalizowania swego kulturowego i cywilizacyjnego znaczenia, ale i przed rugowaniem na obrzeża prowadzonych dziś cywilizacyjnych uporządkowań czy nawet spychaniem poza ich marginesy. Koncepcja prymatu nauki $\mathrm{w}$ tworzeniu nowych paradygmatów kulturowych prowadząca w konsekwencji do marginalizowania (odrzucania) tradycji humanistycznych zyskuje dziś spore grono zwolenników. Obroną humanistyki stały się propozycje nieustannego ponawiania dialogu i - oczywiście - nowe metafory przestrzenne budujące wizję koncyliacji między zwaśnionymi stronami. $W$ rozważaniach związanych $\mathrm{z}$ najnowszym etapem rozwoju debaty na temat "trzeciej kultury” Ryszard Kluszczyński wskazywał na długą historię prób stworzenia wspólnej - zgodnej i harmonijnej - płaszczyzny rozwoju humanistyki, nauk ścisłych i sztuki, pozostających ze sobą $\mathrm{w}$ rozmaitych relacjach, bez dominacji wartości humanistycznych, ale i bez prymatu nauk ścisłych. Podkreślał przy tym, że dopiero wtedy: „Związek ten możemy określić mianem dialogu. [...] Inicjowana przez twórców konwersacja między tymi sferami tworzy dzieła, które doskonale reprezentują świat symbolizowany przez kategorię trzeciej kultury" ${ }^{28}$. Dialog, konwersacja, rozmowa, podobnie jak spór, kłótnia czy wymiana (nie)możliwych do uzgodnienia poglądów wymaga przestrzeni spotkania - dla Kluszczyńskiego jest nią przede wszystkim sfera działania nowych technik cyfrowych i medialnych.

Konieczność podejmowania ciągłych prób nawiązania kontaktu pomiędzy wszelkimi dziedzinami ludzkiej aktywności zdaje się oczywistością wąska specjalizacja prowadzi nieuchronnie do marginalizacji działań. Prowadząc rozważania z nieco innych pozycji, Roger F. Malina do opisu współczesnej sytuacji cywilizacyjnej użył metafory delty rzecznej - o ruchomej, nieprzewidywalnej naturze, odnogach zmieniających bieg, łączących się i rozszczepiających (lub zamulających i znikających). Uznając deltę za twór zarazem rozdzielający terytoria, ale i pozostający płynnym i zmiennokształtnym łącznikiem między nimi, zwrócił uwagę na inny aspekt globalizacji, czyli pozytywne (w jego mniemaniu) skutki ujednolicania się środków porozumienia:

Pokolenie wieku cyfrowego biegle posługuje się dialektem używanym po obu stronach rzeki i taki wspólny język wymaga wspólnych ontologii oraz ewentualnie związanych z nimi epistemologii. Taki proces budowania wspólnego

28 R. W. Kluszczyński, Wstęp, w: W stronę trzeciej kultury. Koegzystencja sztuki, nauki i technologii, red. R.W. Kluszczyński, Gdańsk 2016, s. 12. 
języka umożliwia handel i wymianę barterową, a nie asymilację i jest z pewnością czynnikiem sprzyjającym kreatywności i innowacyjności po obu stronach rzeki $^{29}$.

Tworząc tę przestrzenną wizję badacz przedstawił obraz możliwego do zażegnania - oczywiście w procesie długotrwałych mediacji - konfliktu mieszkańców dwóch rozdzielonych (po części trwale, a dla niego bez wątpienia słusznie) terytoriów. Podkreślał jednak, że powstanie nowego, wspólnego języka gwarantuje skłóconym „plemionom” porozumienie, z którego wyeliminować będzie można wzajemną niechęć, agresję i poczucie obcości. Nadchodzące zmiany budujące nową przestrzeń dialogu - czy raczej polilogu - mogą doprowadzić do istotnych przekształceń w obiegach komunikacyjnych.

Nowe "pokolenia wieku cyfrowego", dla których szczególnie istotnym, doświadczalnym trybem funkcjonowania okazuje się zacieranie różnic między tym, co wewnętrzne, a tym, co zewnętrzne, między podmiotem a światem, percypowaniem przestrzeni a jej (re)konstruowaniem, wytworzą z pewnością - być może w nieodległej przyszłości - sieć nowych szlaków komunikacyjnych w konstytuującym się nowym terytorium wymiany kulturowego dziedzictwa.

\section{Bibliografia}

Abramowska Janina (1978), Peregrynacja, w: Przestrzeń i literatura, red. M. Głowiński, A. Okopień-Sławińska, Wrocław: Ossolineum, s. 125-158.

Agamben Giorgio (2010), O zaletach i niedogodnościach życia wśród widm, w: G. Agamben, Nagość, przeł. K. Żaboklicki, Warszawa: W.A.B., s. 47-52.

Bachelard Gaston (1976), Poetyka przestrzeni: szuflada, kufry i szafy, przeł. W. Krzemień, „Pamiętnik Literacki”, nr 1, s. 233-243.

Bachman-Medick Doris (2012), Spatial Turn, w: D. Bachman-Medick, Cultural Turns. Nowe kierunki w naukach o kulturze, przeł. K. Krzemieniowa, Warszawa: Oficyna Naukowa, s. 335-389.

Bauman Zygmunt (2018), Retrotopia. Jak rządzi nami przeszłość, przeł. K. Lebek, Warszawa: PWN.

Chutnik Sylwia (2014), Zabawy w pamięć i genderowy obraz miasta. Próby konceptualizacji praktycznej, „Teksty Drugie”, nr 6, s. 116-128.

${ }^{29}$ R.F. Malina, Trzecia kultura? Od sztuki do nauki i z powrotem, przeł. M. Grabarczyk, w: W strone trzeciej kultury, s. 28-29. 
Czaja Dariusz (2013), Nie-miejsca. Przybliżenia, rewizje, w: Inne przestrzenie, inne miejsca. Mapy i terytoria, red. D. Czaja, Wołowiec: Wydawnictwo Czarne, s. 7-26.

Czermińska Małgorzata (2011), Miejsca autobiograficzne. Propozycja w ramach geopoetyki, „Teksty Drugie”, nr 5, s. 183-200.

Czermińska Małgorzata (2015), Tożsamość kształtowana w pamięci miejsca, w: Kulturowa historia literatury, red. A. Łebkowska, W. Bolecki, Warszawa: Wydawnictwo IBL PAN, s. 145-160.

Dostal W., Gincrich A. (2008), Antropologia miasta, przeł. M. Sadurska, w: Encyklopedia antropologii społeczno-kulturowej, red. A. Barnard, J. Spencer, Warszawa: Oficyna Wydawnicza Volumen.

Genette Gérard (1978), Przestrzeń i język, przeł. A.W. Labuda, „Pamiętnik Literacki”, z. 1, s. 227-232.

Kluszczyński Ryszard W. (2016), Wstęp, w: W stronę trzeciej kultury. Koegzystencja sztuki, nauki i technologii, red. R.W. Kluszczyński, Gdańsk: Omikron, s. 6-14.

Kunce Aleksandra (2016), Człowiek lokalny. Rozważania umiejscowione, Katowice: Wydawnictwo Uniwersytetu Śląskiego.

Łotman Jurij M. (1976), Problem przestrzeni artystycznej, przeł. J. Faryno, „Pamiętnik Literacki", z. 1, s. 213-226.

Malina Roger F. (2016), Trzecia kultura? Od sztuki do nauki i z powrotem, przeł. M. Grabarczyk, w: W strone trzeciej kultury. Koegzystencja sztuki, nauki i technologii, red. R.W. Kluszczyński, Gdańsk: Omikron, s. 22-31.

Mikołajczak Małgorzata (2017), Regiopoetyka? Wstępne uwagi na temat pewnego projektu, „Poznańskie Studia Polonistyczne. Seria Literacka”, nr 30, s. 67-87.

Lewicka M., Miejsce (2014), w: Modi memorandi. Leksykon kultury pamięci, red. M. Saryusz-Wolska, R. Traba, Warszawa: Wydawnictwo Naukowe Scholar.

Nycz Ryszard (2010), Tekstowe doświadczenia, „Teksty Drugie”, nr 1/2, s. 6-12.

Nycz Ryszard (2017), Nowa humanistyka w Polsce: kilka bardzo subiektywnych obserwacji, koniektur, refutacji, „Teksty Drugie”, nr 1, s. 18-40.

Rewers Ewa (2005), Post-polis. Wstęp do filozofii ponowoczesnego miasta, Kraków: Universitas.

Rybicka Elżbieta (2014), Geopoetyka. Przestrzeń i miejsce we wspótczesnych teoriach i praktykach literackich, Kraków: Universitas.

Skórzyńska Agata (2017), Praxis i miasto. Ćwiczenia z kulturowych badań angażujących, Warszawa: Wydawnictwo IBL PAN.

Sławiński Janusz (1978), Przestrzeń w literaturze: elementarne rozróżnienia i wstępne oczywistości, w: Przestrzeń i literatura, red. M. Głowiński, A. Okopień-Sławińska, Wrocław: Ossolineum, s. 9-22.

Szalewska Katarzyna (2017), Urbanalia - miasto i jego teksty. Humanistyczne studia miejskie, Gdańsk: Słowo/obraz terytoria.

Zielińska Marta (2014), Krajobraz po zwrocie, „Teksty Drugie”, nr 6, s. 13-17. 


\title{
On Diversification of Spatial Categories: Profits and Losses
}

\begin{abstract}
The article considers the consequences of spatial turn in literary studies. This turn did not limit itself merely to the creation of a new methodology and research tools. Instead it covered a much wider scope, as it allowed conclusions to be drawn not only on cultural discourse but also transformation within other areas of research as politics, patterns of common memory and ideology, as well as a change in the processes of establishing the rules of social life. The awareness of the extent to which space determines the conditions of existence was directly linked to the perception of human activity as inherently "located". The growing interest into the spatial dimension of individual and collective experience provides an insight into the issue from a broader perspective. At the same time the topographical turn contributed to the reformulation of other basic terms such as language, subject, culture, literary and artistic practice, and finally, the research and the researcher's position in its own right.
\end{abstract}

Keywords: spatial turn, cultural studies, topographical discourse, site, space 